\title{
Methodological approach to development and implementation of the Small Nuclear Power Plants program
}

\author{
Victor Semenov ${ }^{1, *}$, Tatiana Shchepetina ${ }^{2}$, Vladimir Polevanov ${ }^{3}$, Yuri Savchenko ${ }^{4}$, and Sergei Popov $^{5}$ \\ ${ }^{1}$ Voronezh State Technical University, Department of Nuclear Power Plants, Russia \\ ${ }^{2}$ Kurchatov Institute National Research Center, Laboratory of Perspective Concepts, Russia \\ ${ }^{3}$ Federal Agency for Subsoil Use GeoExpertiza, Russia \\ ${ }^{4}$ International Transport Academy, Russia \\ ${ }^{5}$ Melentiev Energy Systems Institute SB RAS, Department of Complex and Regional Problems in Energy, Russia
}

\begin{abstract}
The article considers perspectives and institutions for innovative nuclear energy subsector - a small and medium-sized nuclear power plants (SNP). The features of the technologies, prospective sites for their introduction, topics for priority research work, as well as mechanisms for the creation of a new sub-sector of nuclear energy are briefly discussed. The advantages and opportunities of such approach to the energy supply of autonomous and isolated consumers located primarily in remote areas and in the Arctic are indicated. Special attention is paid to the problems of technological and operational safety, economic efficiency, and personnel training. The methodological framework provides a brief integrated description of the possibilities provided by dual-use technologies in solving national economic issues; a list of priority research areas to clarify assessments of the financial and economic efficiency of the SNP subsystem within the Russian nuclear energy industry; as well as proposals for personnel training to ensure a trouble-free and efficient Program implementation process.
\end{abstract}

Keywords. Nuclear energy, small reactors, program, technical security, economic efficiency, human resources.

\section{Introduction}

The world has entered into a technological retrofitting of the economy's energy segments. In the global energy system, new infrastructural technological accents of the international competitive confrontation of the leading powers have emerged, including for the political purposes of global domination. The development of hydrogen energy will essentially lead to a new technological order in industry, in the economy as a whole, and even have a potential to change the quality of life. This means that an influx of investment capital is expected into this technological segment to create a new energy infrastructure.

The modern world clearly shows a change of an energy carriers structure to a hydrogen economy based on cheap nuclear energy. Figure 1 shows the changing pattern of the World's final energy consumption, whereby gases, including hydrogen, will become the predominant fuel by 2050 . [1]
At the same time, the primary energy supply structure will change significantly, as the consumption of coal and hydrocarbons will also change significantly due to an increased share of renewable and nuclear energy. The International Renewable Energy Agency IRENA was established in 2009 to coordinate the smooth global transition from fossil to renewable energy.

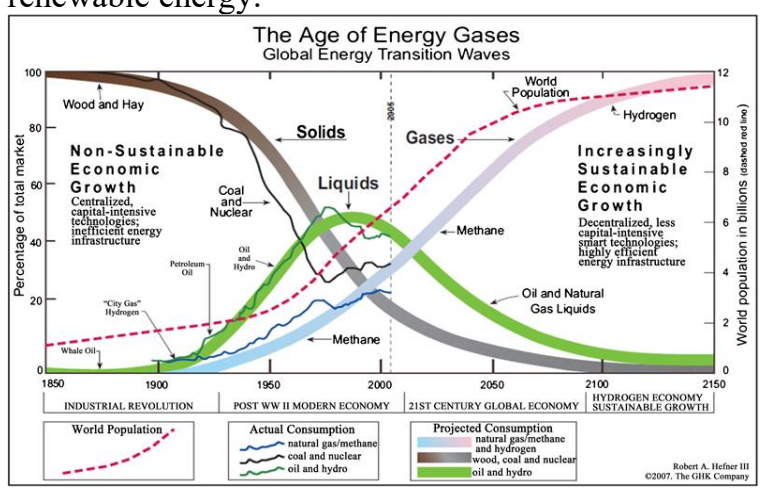

Fig. 1 The energy carriers structure changes

${ }^{*}$ Corresponding author: semenov.v.p@ya.ru 
The importance of the peaceful use of nuclear energy issues led the UN to the creation of the IAEA in 1957. In recent years, the solution of the problem to expand utilisation of the nuclear energy has led to the development of small reactors and modular power plants (SNP). Thus, five projects on this topic are currently being implemented. [2]

"Nuclear generation as a clean source of energy will be a way to reduce the UK's carbon footprint on a large scale," The Times quotes the Prime Minister of the United Kingdom, Boris Johnson, who announced a nuclear renaissance. [3] The government has announced funding of 500 million pounds for Rolls Royce to build small modular reactors in Yorkshire, Lancashire and Cheshire, which will create 40,000 jobs. Each station will produce enough energy to meet the needs of 750,000 homes. [4]

In the Russian Federation, current trends in lowcarbon and carbon-free energy are reflected in the acts of the state administration of the President and the Government-from concept documents to specific instructions to Rosatom. This system of public administration prescribes the early development of SNP sub-industry.

Pilot project for the creation of a SNP sub-sector in nuclear power industry, the Draft Program [5] is aimed at implementing the Decree of the President of the Russian Federation from 13.05.2019 No. 216 "On the Approval of the Energy Security Doctrine of the Russian Federation", the instructions of the President of the Russian Federation formulated by the Decree of the President of the Russian Federation of 20 April 2020 No. 270 and the Strategy for the Economic Development within a framework of the greenhouse gas emissions constraints.

The modular design facilitates the mass production of components and allows to scale the station depending on the regional or single remote consumer's power demand. In many countries, the life of traditional nuclear power facilities is coming to an end. The modular reactors will help to keep the nuclear component in the energy balance and to reduce carbon emissions by 2050. "Nuclear energy should have a place at the common table: it is not logical and unscientific to worry about climate change and at the same time abandon such a clean, low-carbon source as nuclear energy," IAEA Director General Rafal Grossi said. [4]

The successful development of the hydrogen infrastructure - from production, storage, and transportation to the final energy consumption, and the development of hydrogen technologies, would became possible only when the appropriate system conditions would be available. In relation to the hydrogen technologies in the Russian nuclear industry, unique competence pool has been created over the previous decades, which no other country in the world possessed so far. First of all, it is a well-preserved manufacturing industry holding the full spectrum of the Soviet and well-integrated latest Russian breakthrough technologies. Combined with innovative management it will create competitive advantages on the world market for the next 10-15 years, and stimulate further development of nuclear and hydrogen energy infrastructure.

Another integral component of the Draft Program is the preserved professional personnel potential of the industry, which has the knowledge, experience and relevant practice of operating nuclear power plants with various capacities and designs. A wide range of SNP applications, their efficiency, reliability in operation, low operating costs over the entire service life and high profitability will allow to reach:

- High energy and environmental safety indicators;

- An acceptable level of return on investment, by creating conditions for the nuclear energy technology clusters (NETC) development, improving the quality of life and rising employment rate;

- The geostrategic advantage;

- The reliability of the human factor.

\section{Safety}

Russia still maintains a priority in SNP technologies, which have been tested by operating more than 7000 reactor-years, with an integrated safety 1000 times higher than for gigawatt-class reactors, a modularaggregate layout manufactured and assembled at factory, and a service life of up to $60-80$ years. The widespread introduction of SNP will solve the most pressing issues of long-term reliable energy supply, reduce tariffs for consumers and guarantee their stability during the entire specified service life in areas with decentralized energy supply. [5]

The authors' analysis of the risks and challenges associated with the energy and environmental safety of various nuclear power technologies points to the clear advantages of SNP (Table 1).

The renewable energy production in the Russian harsh natural environmental, technical (energy quality), economic, and seasonal circumstances, is not enough to meet the growing needs for heat, fresh water and electric energy. It is assumed that SNP will become the basic sources for ensuring the reliability, stability and quality of energy supply in the northern and Arctic territories. [6]

The most important factor to improve the technical system's safety is the availability of qualified and trained personnel. The stability of any system is equal to the stability of its weakest link, which is the staff's professional reliability. Due to the existing restrictions, such a weak link are the peoples who determine the influence of the human factor on safety of the technical and economic systems.

In nuclear power projects, we are still consciously taking a "power risk" for the sake of short-term "economic benefits", without thinking about upcoming problems. As an alternative to large (gigawatt class) reactors, the program for creating the SNP sub-sector within nuclear energy industry will bring the holistic benefits by reducing economic, environmental, operational, and nuclear radiation 
risks. All these risks are complex, but each contains a human factor.

Transition to the implementation of SNP technologies instead of large reactor units will reduce the specific weight of a possible negative event at all stages of the life cycle of an individual Nuclear Power Plant. A significant role in this effect is assigned to the human factor - at the design, construction, operation and decommissioning stages for facilities within nuclear power infrastructure. [7]

Table 1 Advantages of energy and environmental safety of AFM/CM

\begin{tabular}{|c|c|c|}
\hline Criteria & Gigawatt-class reactors & Modular SNP \\
\hline $\begin{array}{l}\text { Risks related to nuclear and } \\
\text { radiation safety }\end{array}$ & Estimated by probabilistic methods & $\begin{array}{l}\text { Both the probability of risk and the magnitude of the damage } \\
\text { itself are deterministically reduced. No POA }\end{array}$ \\
\hline $\begin{array}{l}\text { Energy security } \\
\text { (infrastructure risks) }\end{array}$ & $\begin{array}{l}\text { Huge network risks and the entire } \\
\text { infrastructure }\end{array}$ & $\begin{array}{l}\text { Integration into the local power grid. Flexibility to increase } \\
\text { generating capacity. Proximity to the consumer. Optimal power } \\
\text { grid structure. }\end{array}$ \\
\hline "capacity risk" & $\begin{array}{l}\text { The minimum power reserve in the } \\
\text { power system is equal to the power of the } \\
\text { block. }\end{array}$ & $\begin{array}{l}\text { The minimum power reserve in the power system is equal to the } \\
\text { power of the backup module and the power mobility }(10-100 \%) \\
\text { for each consumer }(100-300-650 \mathrm{MW})\end{array}$ \\
\hline $\begin{array}{l}\text { Alternative approach to } \\
\text { nuclear fuel reloading }\end{array}$ & $\begin{array}{l}\text { Overload every two years. Spent nuclear } \\
\text { fuel storage facility. Spent nuclear fuel } \\
\text { and radioactive waste removal. Dose } \\
\text { load. }\end{array}$ & $\begin{array}{l}\text { The active zone campaign is 10-15 years old. Reloading together } \\
\text { with the reactor plant under factory conditions. No dose loads. }\end{array}$ \\
\hline $\begin{array}{l}\text { Use for technological } \\
\text { purposes }\end{array}$ & Not anytime soon & Wide opportunities for getting closer to localities and industries \\
\hline $\begin{array}{l}\text { Risks at the } \\
\text { decommissioning stage }\end{array}$ & $\begin{array}{l}\text { Large dismantling } \text { volume, high } \\
\text { radiation doses }\end{array}$ & $\begin{array}{l}\text { Large-scale dismantling. Both the probability of risks and the } \\
\text { amount of exposure are reduced }\end{array}$ \\
\hline Environmental safety & Limited by placement & $\begin{array}{l}\text { Significant when replacing more than } 90 \% \text { of the carbon-based } \\
\text { generation }\end{array}$ \\
\hline $\begin{array}{l}\text { Availability of placement } \\
\text { sites }\end{array}$ & Limited & Within the framework of regional energy almost everywhere \\
\hline Industrial site reuse & Almost impossible & Possible \\
\hline Public acceptance & $\begin{array}{l}\text { Psychological barriers (especially after } \\
\text { the Chernobyl and Fukushima accidents) }\end{array}$ & $\begin{array}{l}\text { The possibility of visual evidence of increased safety of AFM/SM } \\
\text { blocks }\end{array}$ \\
\hline
\end{tabular}

\section{Economic issues}

The implementation of the Draft Program will contribute to the solution of many technical, economic, social and political issues at the Arctic territories [8]:

- To ensure high level of energy and environmental safety, and long-term reliability of energy systems in extreme climatic conditions;

- To create energy supply for innovative transportation systems, including those that are independent of natural and climatic conditions;

- To promote the development of mineral resources in remote areas of Russia, primarily in the Arctic, Siberia, and the Far East;

- To provide cost-effective energy supply for isolated industrial clusters and logistic hubs;

- To increase environmental safety by reduction of greenhouse gas emissions and environmental pollutions by substituting fossil fuel facilities;

- To provide attractive environment for domestic and international investors;

- To promote economy diversification;

- To become a guarantor of the territorial integrity and national security of the Russian Federation.

In addition, the start of serial production of power generating capacities based on SNP will allow [9]:

- implement systematically Russia's proven SNP technologies (a modular-aggregate layout, manufactured at factory with high quality standards, long service life -60 to 80 years, integrated operational safety);
- $\quad$ significantly reduce tariffs for energy consumers in the Far North and the Far East [10], when life cycle cost of electricity is assessed;

- transition to new standards of life quality in the sparsely populated northern territories of Russia and for indigenous population;

- introduce hydrogen as a new energy carrier, develop its storage and transportation infrastructure for use in transport and buildings;

- avoid the potential risks and consequences of introducing a carbon tax when exporting Russian products with a significant "carbon footprint";

- develop projects to substitute imported equipment and promote innovative technologies.

Next, we will consider the tasks and problems that the Program is aimed at solving, the proposed objects that will require clarification of the indicators of the economic efficiency of using SNP technologies, and also propose a number of mechanisms that will contribute to the implementation of the Program.

Modular SNP systems are able to provide energy services for island territories and hard-to-reach places of Russia, Asia, Africa, and Latin America [11], thus ensuring:

- creation of a reliable system for life support and energy self-sufficiency of territories;

- production of fresh water, hydrogen, etc.;

- development of the mineral extraction and processing facilities, including the formation of nuclear power technology complexes and clusters (NETC);

- expanding the resource base of hydrocarbons by increasing energy supply. 


\subsection{Rising electricity prices}

According to some estimations [12], over the next decade businesses will pay more than 11 trillion rubles for various energy development programs and crosssubsidies. The price of electricity and fee for capacity access for industrial consumers consists of competitive components and various surcharges, subject to cross-subsidizing. This means that almost half of the industry's losses is the payment for the construction of new generation facilities under power supply contracts. The control of electricity prices for the population will cost about 3 trillion rubles, and it should be covered by business. There are even more such surcharges within the power tariff, accounted for 14 to 19 percent of total electricity price, depending on the calculation method.

At the same time, the quality of the electricity at the power market has been rapidly deteriorating for several years. In order to avoid payments for someone else's inefficiency, along with rising cost of network services, electricity consumers, primarily energyintensive industry, actively switching to their own energy sources.

\subsection{Perspective consumers of the SNP technologies}

Power generation in most of Russia territories is local in nature (depicted by yellow and grey colours at Figure 2). Such a system of isolated power plants is operated on fossil fuels, primarily diesel along the Northern Sea Route and at small remote consumers. The logistics of fuel delivery require multiply sea-land and river-land transhipments, increasing cost and significantly hindering economic development of the territories. The existing structure of power generation, based on fossil fuels, the business at the Arctic, Siberia and the Far East territories is tied to the costs of the so called "northern delivery" and logistic surcharges.

The potential demand for promising SNP sites in the Russian domestic market has been identified so far at $20 \mathrm{GW}$.

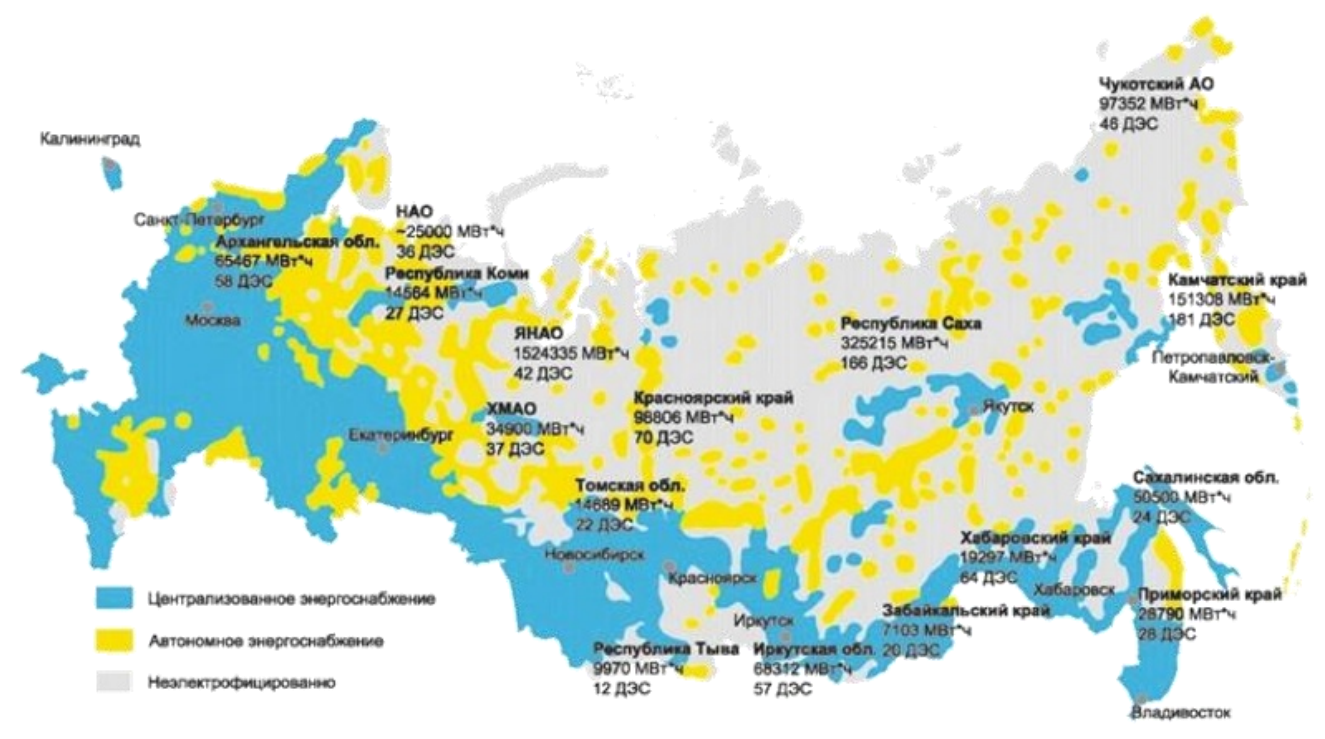

Fig. 2 Geospatial pattern of power generation in the Russian Federation

The development of these regions is hindered by the lack of reliable autonomous power generators, which are independent of the complex fuel logistics, has short construction cycle at place, avoids grid infrastructure and compline with tight environmental regulation, including strengthening Paris Agreement.

An alternative to the surface shipping along the North Sea Route is the conversion of a heavy rocket submarines into an all-weather, independent of natural factors and ice conditions, underwater transport.

Malachite Design Bureau combine the nuclear submarine technology and gas carrier function. The main route will take up to 17 knots submersible, traffic in ports and loading operations will be held in the surface position. Cargo-carrying capacity is similar to that of a modern gas carrier: length $360 \mathrm{~m}$, width 70 $\mathrm{m}$, height $30 \mathrm{~m}$, draft $12-13 \mathrm{~m}$; satisfies requirements for calling at ports of destination - port of Sabetta and Petropavlovsk-Kamchatsky. This is a serious alternative to powerful Arc7-class LNG carriers and icebreaking in winter navigation, which increases the cost of transportation. A nuclear-powered underwater LNG carrier with a crew of 25-28 (and as an option unmanned) would provide year-round expedited transportation from the perspective Arctic LNG export facilities to transhipment points in Kamchatka and Murmansk, regardless of climatic and environmental conditions. Five to eight submarine nuclear-powered gas carriers could be built into the infrastructure of an inter-sectoral control centre of the North Sea Route for the LNG or hydrogen export since 2024-2027. [13]

Yet another logistic infrastructure in Arctic is the High-speed Transcontinental Arctic Tunnel (HSAT) in the permafrost at a depth of $45-65 \mathrm{~m}$ in the relict freezing zone. Built with a $3000 \mathrm{~mm}$ track, a 500t load capacity of each car, freight speed $120 \mathrm{~km} / \mathrm{h}$ and 160 $\mathrm{km} / \mathrm{h}$ for passenger traffic, the tunnel in permafrost will connect all ports and polar cities of the Arctic Siberia and the Russian Far East, connecting 11 million northerners. The prospect of International 
HSAT includes another six Polar countries along the 20 to 85 meridian. [14] The energy requirements for the construction and operation of HSAT and the new Arctic cities are expected to be met by 25 modular underground SNPs, which are half the cost of the above-ground version. The use of the Wenchester tunnel excavation technology by using laser slotting and undercutting, increases the rate of tunnelling to 50 $\mathrm{m} /$ day at least. The main feature of permafrost that provides a competitive advantage for this project is the absence of groundwater movement, which saves the cost of finishing the interior walls of the HSAT's linear section. Tunnelling eliminates the need to install any bridge crossings, the extensive use of timber and other construction materials. [7]

The main contender for energy supplied from the SNP in the Arctic mining industry is Baim deposit in Chukchi Autonomous District. It contains $9.5 \mathrm{mln}$ tonnes of copper and $16.5 \mathrm{~m}$ ounces of gold. KAZ Minerals is ready to build a mine based on the deposit, but the Russian side must ensure its power supply. To supply power to the Baimsky mining and processing plant, up to $350 \mathrm{MW}$ of new generation capacity should be constructed. Two schemes of energy supply are suggested. One is five floating SMPs, utilising Russian technology with the cost of 160 billion rubles (four in operation, one in reserve "for the purpose of fuel reloading and repair"), total capacity of $500 \mathrm{MW}$ and tariff 6.45 rubles per $\mathrm{kWh}$. The alternative option is floating LNG power plant at cost of 82 bln rubles and tariff 6.34 rub per kWh. However, the latter didn't take into account operational fuel costs, it's lifetime is three times less, possessing imported equipment which

Table 2 Qualitative comparison of the power supply

\begin{tabular}{|c|c|c|}
\hline Criteria & $\begin{array}{c}\text { Large capacity Nuclear Power, Diesel, Wind, } \\
\text { and Large PV Plants }\end{array}$ & Modular SNP \\
\hline $\begin{array}{l}\text { Costs at the stage of } \\
\text { choosing a } \\
\text { construction site }\end{array}$ & $\begin{array}{l}\text { Quite large (10-15 years for Large capacity } \\
\text { Nuclear Power Plants), comparable to SNP for the } \\
\text { rest types of generators. }\end{array}$ & $\begin{array}{l}\text { Construction time is } 2-4 \text { years, factory construction conditions, } \\
\text { modularity, the whole complex of works on one site. The } \\
\text { exception is the Baltic Plant due to the risks of transportation to } \\
\text { Murmansk. }\end{array}$ \\
\hline $\begin{array}{l}\text { The presence of an } \\
\text { investor }\end{array}$ & Only large companies, at least $\$ 10$ billion. & $\begin{array}{l}\text { Significant expansion of the circle of investors, multiple smaller } \\
\text { risks }\end{array}$ \\
\hline Capital expenditures & $\begin{array}{l}\text { Construction of the power transmission lines, } \\
\text { construction time extension. }\end{array}$ & $\begin{array}{l}\text { Projects for the construction of structures and transport } \\
\text { infrastructure (power transmission lines), lengthening the } \\
\text { construction time. } \\
\text { Reduced capital costs at the same level of installed capacity due } \\
\text { to seriality, modularity and factory quality }\end{array}$ \\
\hline $\begin{array}{l}\text { Risks associated with } \\
\text { power outages }\end{array}$ & $\begin{array}{l}\text { Risks are present at energy generation and } \\
\text { transportation facilities. Great damage to } \\
\text { consumers. }\end{array}$ & $\begin{array}{l}\text { The risks are present at the generation facilities, significantly } \\
\text { less for the virtually absent network component of the energy } \\
\text { infrastructure. } \\
\text { The amount of damage is reduced several times due to } \\
\text { modularity. }\end{array}$ \\
\hline $\begin{array}{l}\text { Value added, } \\
\text { profitability }\end{array}$ & $\begin{array}{l}\text { Not in the near future, constraints only on power } \\
\text { generation }\end{array}$ & $\begin{array}{l}\text { Generation near the consumer. } \\
\text { High integrated profitability, cogeneration, creation of energy } \\
\text { technology complexes and energy supply systems at the local } \\
\text { level (including in the production of hydrocarbons. }\end{array}$ \\
\hline Cost reduction & $\begin{array}{l}\text { High capital (wind and solar, when capacity factor } \\
\text { and needs for energy storage are taking into } \\
\text { account) and operating costs (diesel, network } \\
\text { infrastructure-power lines), the need for } \\
\text { redundancy, heat and electricity consumption for } \\
\text { their own needs, losses in the networks. }\end{array}$ & $\begin{array}{l}\text { Increasing the energy capacity of the Ship Repair Centers - } \\
\text { closed life cycle chains in one place at United Shipbuilding } \\
\text { Company. } \\
\text { Increase in the capacity factor and the efficiency factor. } \\
\text { Ensuring the sustainability and survivability of hybrid energy. }\end{array}$ \\
\hline $\begin{array}{l}\text { Technological } \\
\text { competencies and } \\
\text { infrastructure } \\
\text { development }\end{array}$ & Limited by the power unit technology & $\begin{array}{l}\text { Development of competencies within the economy of the AETC } \\
\text { territory. Guaranteed lifetime employment. Educational center, } \\
\text { scientific and technological complex, advanced research of the } \\
\text { Arctic and the South seas. }\end{array}$ \\
\hline Export opportunities & $\begin{array}{l}\text { Limited, the market is relatively small with high } \\
\text { level of competition. }\end{array}$ & $\begin{array}{l}\text { The emergence of new market niches and competitive } \\
\text { advantages of the nuclear-industrial complex (electricity, heat, } \\
\text { cold, fresh water, hydrogen, etc.) }\end{array}$ \\
\hline Insurance & Not available in full & It is possible for many programs \\
\hline
\end{tabular}


The results will be useful in developing a balance of interests in the process of establishing publicprivate partnerships in solving the problems of creating clean energy and developing socio-economic infrastructure in regions that are not part of the unified energy system of the Russian Federation. Thus, by creating their own commercial reserve, investors in this energy segment will find themselves in the global energy transition trend.

The most urgent and most popular are the estimates of the electricity cost, taking into account the full life cycle. They are used for investment analysis of tariff formation. [16] The cost of generation using a nuclear power plant, for example, a power unit with a Shelf reactor, will be 14.2 rubles $/ \mathrm{kWh}$ in condensation mode, and 4200 rubles/Gcal in heating mode for the entire service life. At the same time, according to the official information source [4], for settlements in the Republic of Sakha (Yakutia) the range of the electricity tariff is from 25 to 389 rubles $/ \mathrm{kWh}$, and heat tariff ranging from 3700 to 28,000 rubles/Gcal.

In technologically isolated areas with decentralised energy generation and long-distance fuel logistics, SNP provides lower cost of electricity and heat compared to competing technologies - diesel, wind and solar (utility PV), while maintaining high standards of reliability and environmental friendliness. As a rule, technologies are evaluated and compared according to the following technical and economic parameters: capacity factor, specific fuel consumption, fuel price, capital and operating costs, redundancy costs, auxiliary energy consumption for heat and power generation, grid losses and costs for grid construction and operation.

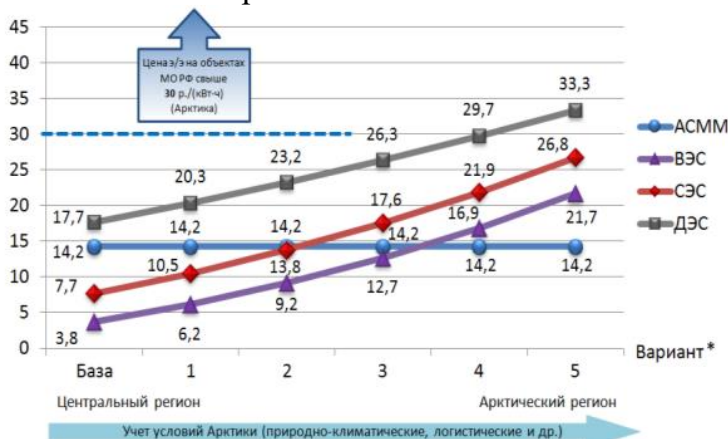

Fig. 3 The cost of electricity generated by SNP, wind, diesel, and solar utilities, depending on natural and logistics conditions

Indicators for power supply systems built on the basis of SNP technologies, taking into account their modularity, proven by more than 7000 reactor-years practice, with high integral safety under extreme conditions, show the possibility to solve the most urgent issues of power supply and reduce tariffs for consumers, to keep them stable during their service life up to 60-80 years. This fact, as a rule, is underestimated when estimating on the basis of comparative calculations with alternative generation technologies - combined heat and power plants, wind farms, solar power plants (Fig.3).

Another line of research should confirm, on the basis of uncertainty zone exploration methods, that proper assumptions on seriality, modularity, manufacturing quality and short construction time of anarerr facilitios haced on CNID tarhnolomer mould laad

ГРАФИК ВЛОЖЕНИЯ СРЕДСТВ ПРИ СООРУЖЕНИИ ОДНОГО БЛОКА БОЛЬШОЙ МОЩНОСТИ И ЧЕТЫРЕХ БЛОКОВ ТОЙ ЖЕ СУММАРНОЙ мощности

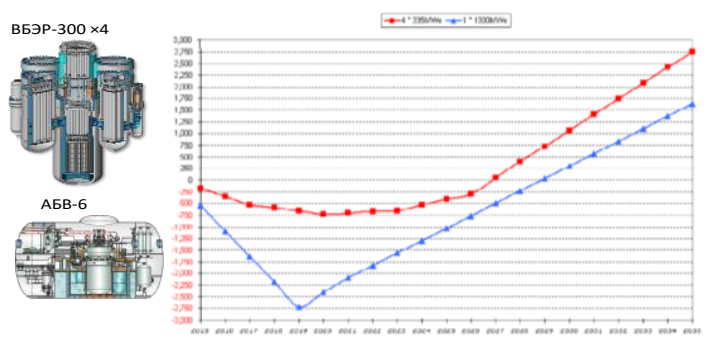

Fig. 4 Reduction of ASMM capital expenditures at a similar level of base capacity

The lower capital intensity of SNP blocks due to "small-batch" investment, reduced financial risk and the possibility of conventional insurance makes it possible to significantly increase the investment attractiveness of projects under the Program. Thus, the phased commissioning of power units, carried out in queues with a step-by-step increase in capacity, allows to reduce the payback period of capital investments due to an earlier start of the issuance of commercial products and an earlier start of the loan repayment, compared to a power unit based on a gigawatt class capacity reactor.

Modular SNP can be placed directly in the centers of energy consumption, which eliminates the needs for transmission lines. Substantial reductions in grid maintenance costs in harsh climatic, geographical and arctic conditions over a large area of Russia will increase the efficiency of the Project and the competitiveness of SNP technologies.

At the same time, the possibilities of using "capacity insurance" are expanded, which also allows us to achieve the advantages of this technology in terms of mitigating a multitude of risks.

The use of fully prefabricated modular structures (similar to Novatek's construction of the Yamal LNG plant) eliminates the risks associated with human error during construction in harsh climatic conditions. In addition, construction time is reduced due to the rejection of logistic patterns with numerous transshipments and short periods of water and seasonal roads availability.

Another promising area of research into the SNP efficiency is comprehensive, systematic evaluation of technologies based on their full life cycle. Currently, when choosing a project by comparing and considering different alternatives, major criteria is either overnight costs, or specific capital costs. That is not always appropriate from the standpoint of a systematic approach, or lifecycle of the object. Savings in one case do not always lead to savings in general, but actually - to large costs or even losses.

The costs should be calculated for the entire life cycle of the project up to its decommissioning, when the prospect of SNP application in local power systems in a capacity range of 50-100-300 MW is considered, and the absence of potential danger should be provided 
when load is changing within $10-100 \%$ of the reactor capacity. This type of mistakes also includes direct lobbying of plant types without comprehensive expertise and comparative analysis, taking into account consumer requirements, limiting innovative developments to the well-known formula "referential solutions", which simply leads to stagnation of promising technology developments.

\subsection{New institutions and mechanisms for the SNP Program's enforcement}

We believe that the integrated driver for the development of the SNP Project in the framework of a public-private partnership could be private investment in point-to-point small nuclear generating facilities and related infrastructure of energy technology complexes (NETC). This mechanism is of particular importance in a view of the need to address the development and commercialisation of hydrogen technologies in Russia.

A new financial scheme for the investment of the SNP project is proposed - the Joint Extended Reinvestment Leasing Agreement (JELA). It provides a technical credit for the construction of the SNP against the future supply of electricity and heat at a guaranteed tariff to industrial enterprises (interested business actors) and the entire infrastructure of the special economic zones for an extended period. In this way, economically justified and environmentally acceptable development of the Arctic and a number of other territories of the Russian Federation will be ensured.

It is proposed that the following indicators be included in the mandatory performance evaluation criteria for state elites (investors, governors, heads of state corporations, ministries and agencies, etc.):

a) creation of enterprises (jobs and development of competencies) of industrial-production type to promote development of the city's infrastructure;

b) creation and/or initiation of the special economic zones status of State Corporations for the implementation of National Projects in cities, towns and depressed regions of the Russian Federation;

c) creation of a social infrastructure for combining experience and youth Centers for patriotic education, mentoring, and technical creativity of young people, in order to attract veteran professionals to expert work and career guidance for young people;

d) reducing prices in the consumer and service markets, solving demography issues, consolidating the population within the regions, and improving the quality of life. [4]

A new mechanism should be introduced to create a system for attracting large operators and holding companies in the energy, mining, and transport sectors to orders modular SNP for local power supply systems development. It should involve such promising megaprojects of the Russia's economic development as construction and operation of innovative interconnected logistics systems, development of large mineral deposits, introduction of new and innovative transport and life-supporting energy technologies based on hydrogen energy. The creation of energy infrastructure within the framework of the Project can be integrated with hydrogen technologies, and serve as a driving force for the development of importsubstituting technologies and hardware.

Pilot integrated projects are technological clusters under one roof in the territories of advanced development. They are focused on obtaining clean fresh water, hydrogen, synthetic fuel for local needs, providing energy for the production of new construction materials, and agricultural products in protected ground, creating agricultural and marine farms in areas with unfavourable climatic conditions for agriculture, long-term storage of products, waste processing, and the use of a number of other radiation technologies.

\section{Geopolitics}

The Arctic is becoming an arena of global competition for transport flows and natural resources of global importance. Resources are a powerful reason for stronger countries to participate in their "fair" redistribution. The creation of a large energy infrastructure based on SNP technology will be a factor of "alternative nuclear deterrence" of the US intentions for a permanent presence in the Arctic. It is driven by the need to protect and ensure IAEA control of these facilities, which may be located in $2 / 3$ of the country's decentralized energy supply and in an area of complex logistics for fuel supply.

The Clean Air program and the need to meet the strict limits of the Paris Agreement by 2050 will put the existing generating capacity with high carbon emissions at risk of closure. Re-equipment of strategic submarines for underwater cargo transportation along the North Sea Route (including emergency and/or spot deliveries of $\mathrm{LNG} \& \mathrm{LH}_{2}$ ); creation of the appropriate infrastructure for regular operations of such "undersea cargo express", participation of SNP technologies in the construction and energy supply of a functioning HSAT present a strategic and political factor to protect Russia's Arctic territories and water areas.

\section{Human Resources}

The establishment of personnel education and training centres, combined with an information and technical support operational centre for the fixed and mobile SNP industrial subsystem, will ensure the reliability of the human factor in order to maintain high safety performance at the construction and operation stages of the Programme facilities.

The proposal to integrate training and production processes of the Programme is detailed in [17]. If the level of responsibility, competence and organisation of the staff does not grow in proportion to the new technologies at all stages of the lifecycle of SNP technologies and NETC facilities, one can be sure that no expenditure on technology will pay off.

Recruitment should be preceded by: personnel needs assessment, activity analysis, definition of qualification requirements, development of 
professional standards. In order to solve these tasks it is necessary to establish Training and Professional Development Centres for the SNP personnel (considering the whole line of reactor capacity) and personnel of new (dual) technologies of nuclear power complexes (NETC) in a unified complex of information, analytical and technical support of the SNP operation, internal/external Crisis Centre with the Centre for Advanced Research and Security of the Arctic and South Seas, Data Processing Centre and Project Management Information System. [18]

\section{Conclusions}

The implementation of the Draft Program will allow the creation of a nuclear sub-sector of SNP to solve many technical, economic, social, and political issues [19]:

- to ensure high energy and environmental safety, long-term reliability of energy systems in extreme climatic conditions;

- to create energy supply for new transportation systems, including those that are independent of natural and climatic conditions;

- to promote development of mineral resources in hard-to-reach areas of Russia, primarily in the Arctic, Siberia, and the Far East;

- to ensure cost-effective energy supply to remote isolated industrial clusters and logistics hubs for the North Sea Route and the HSAT;

- to increase the level of environmental safety by significantly reducing greenhouse gas emissions and environmental pollutions when replacing fossil-fuelled energy facilities;

- to provide attractive terms for domestic and international investors;

- to promote the diversification of the economy, the solution of energy, environmental, social, demographic and defence tasks for socioeconomic development of Russia up to the end of this century;

- to become an object of regional advantage, a guarantor of the territorial integrity of the Russian Federation and of National security.

The article points out the intended uses of dual-use technologies within the SNP Draft Programme, highlights the areas of research that need to be carried out to refine a number of technical and economic indicators, justify financial and economic efficiency, and proposes mechanisms for the Programme's implementation. Particular attention is paid to the training of the personnel to ensure the implementation of this Programme.

The implementation of the Energy Sector Development Programme based on SNP technologies will make it possible to reduce electricity prices for industry and the life support systems of the population. A new financing mechanism is proposed for the construction of the Programme facilities.

The work was supported by the grant of the NRC "Kurchatov Institute" (No. 2220 of 23.10.2020); the State Assignment Project (No. FWEU-2021-0004, Registration No. AAAA-
A21-121012090010-7) of the Fundamental Research Program of the Russian Federation for the period 2021-2030.

\section{References}

1. El-Shafie M., Kambara S., Hayakawa Y. "Hydrogen Production Technologies Overview" / Journal of Power and Energy Engineering. -2019 No. 2 pp. 107-154 DOI:10.4236/jpee.2019.71007

2. Small Modular Reactor: flexible and affordable power generation, IAEA, https://www.iaea.org/topics/small-modularreactors

3. "Renaissance", Journal Rosatom Country No. 29 August 2019 (397) p. 3

4. Rabikowska E. "Rolls-Royce: a course on nuclear reactor", Journal Rosatom Country June 2020 No.24 (440) pp. 10-11

5. Semenov V.P. "program for the establishment of a regional energy on the basis of the reactors of small and medium power series of nuclear heat and power plants (plant) floating nuclear power plants (construction) (FNPP) in regions outside of the unified energy system of the Russian Federation" (certificate No. 00011 from 15 Nov 2018 depositing of the result of intellectual activity from $15 \mathrm{Jul} 2011$

6. Chumak D.Yu., Shchepetina T.D. Risk classification as a necessary control element in nuclear power projects // Atomic Energy, vol. 116, No. 2 -2014 pp. 108-113

7. Shchepetina T.D., Udiansky Yu., Chumak D.. Research and classification of risks and their sources for the full life cycle of nuclear power projects //Innovative design. -2014 No. 8, pp. 5670

8. Fauser V.V. Lytkina T.S. Fauser G.N. "Local labor markets of the Russian Arctic: classification by type of activity" / Arctic: ecology and Economics. -2019 No. 2(34) pp. 4-15.

9. Pimenov A.O., Kulikov D.G., Vasiliev A.P., Molokanov N.A. "Low-power nuclear power plants in the Arctic territories: issues of economic feasibility and environmental safety" / Arctic: Ecology and Economics. -2019 No. 2 (34) pp. 120-128

10. Resolution of the State Committee on Pricing Policy of the Republic "On the establishment of post-station tariffs for electric energy produced by Sakhaenergo»

11. Derova T.I. Patent Attorney of the Russian Federation No. 324 of 25.02.2019. "Report on patent research on the topic "the program of the regional energy system creation on the basis of small and medium power series reactors, nuclear heat and power plants, floating nuclear power plants, in regions outside of the unified energy system of the Russian Federation" (certificate No. 00011 from 15 Nov 2018) depositing of the result 
of intellectual activity Semenov V. P. dated $15 \mathrm{Jul}$ 2011

12. For energy the business will pay 11 trln RUB https://www.vedomosti.ru/business/articles/2019 /10/11/813442-biznes-sobstvennuyu-generatsiyu

13. Zaitseva S. "And we have gas in the submarine "/ Journal "Strana Rosatom", December 2019 No. 47 (415) p. 6

14. Savchenko Yu.I. "About the unique project of the Transcontinental tunnel" / Review article 5 of the Russian International Congress on Intelligent Transport Systems, 12-14 Mar 2013

15. Burmistova S. "Putin approved the Rosatom energy project for the GOK in Chukotka for P169 billion" / RIA Novosti 30 Apr 2021

16. "Total Electricity Generation Costs" (OECD 2018, NEA No. 7298) https://www.oecdnea.org/jcms/pl_51110/projected-costs-ofgenerating-electricity-2020-edition

17. Semenov V. P. author's description "Improvement of the system of training, retraining and advanced training of personnel for regional energy and industry in the framework of measures for the implementation of the APEC, PATES Program in regions not included in the unified energy system of the Russian Federation" (certificate No. 00012 21 Nov 2018) depositing the result of intellectual activity of 31 May 2008

18. Masloboev A.V. "The concept of the Center for Advanced Research and ensuring the security of the Arctic" Arctic: Ecology and Economy-2019. No. 2 (34) pp. 129-141

19. Semenov V.P. "Program for the creation of an Information system for project management for the development of regional energy on the basis of ASMM in regions not included in the unified energy system of the Russian Federation" ATEC, PATES in regions not included in the unified energy system of the Russian Federation" (certificate No. 00013/1, 2 of 29 Nov 2018) depositing the result of intellectual activity of 11 Apr 2011 